NOTES ON THREE CASES OF EMPYEMA OF THE MAXILLARY ANTRUM IN WHICH A "BAD SMELL IN THE NOSE" WAS THE ONLY SYMPTOM COMPLAINED OF.

BY ADOLPH BRONNER, M.D , M.R.C.S., SURGEON TO THE BRADFORD FYE AND EAR HOSPITAL; LARYNGOLGGIST TO THE BRADFORD INFIRMARY.

DURING the recent epidemics of influenza one of the common symptoms was severe catarrh of the nares, often of a purulent or muco-purulent nature. In many cases one or more of the accessory cavities of the nose became affectedthe maxillary antrum, the sphenoidal or the ethmoidal cells, most frequently the former. Very few text-books deal at all fully with the diseases of the sphenoidal or ethmoidal cells, and the descriptions of disease of the maxillary antrum are most misleading and exaggerated. We read of exophthalmos, severe pains in the cheek, extensive swelling, copious discharge of offensive pus, \&c. These symptoms certainly do occur in acute or severe cases, but in the large majority of cases the symptoms are not at all well marked. Often the patient complains only of a slight offensive discharge from one side of the nares, and frequently the only subjective symptom is a bad smell in the nose. In the three cases which $I$ am recording the patients complained of nothing else except an occasional bad smell in the nose, which was frequently most offensive and disagreeable. Nor were there any marked changes to be found in the nares except slight hypertrophy of the mucous membrane.

CASE 1 -A woman, aged thirty-five years, single, bad a severe attack of influenza three years ago, accompanied by muco-purulent rhinitis. Since that time she had noticed an occasional and sickly smell in the right nostril, which varied in frequency and intensity. It was often so offensive that the patient felt sick and miserable. When I saw her in February, 1896, the right nostril was apparently normal, with the exception of some thickening of the mucous membrane. Transillumination gave negative results (as in most cases). An exploratory puncture of the antrum was refused, as the patient said that "she did not wish to be experimented on." In July under chloroform I opened up the antrum through the alveolar process. A few drops of offensive pus escaped. A gold pin was attached to the false teeth, which the patient was wearing, and passed into the antrum. This was syringed out daily, and insuffations of aristol and boric acid were used. The smell disappeared after the operation and has not returned.

CASE 2 -A young woman was sent to me in April, 1897, for "polypi in the right nostril" and an offensive smell in the nose. Eight years previously the patient had all the upper teeth removed because they were loose and painful. S:x years ago she first noticed an occasional and offensive smell in the right nostril, which had increased in severity and frequency. There was some hypertrophy of the mucous membrane of the right nostril, but no polypi. I passed a Lichtwitz exploratory trocar through the wall of the lower nasal meatus into the antrum and injected warm boric acid lotion. A large quantity of offensive pus came away through the right nostril, and the patient at once exclaimed, "That is the smell I complain of." The antrum was opened through the alveolar process and treated by insufflations, and recovery followed.

CASE 3.-A married woman, aged sixty-three years, had complained of an occasional and offensive smell in the nose and throat for several years. In the middle meatus of the right nostril there was a pulsating reflex, and on one occasion I could find a little pus in the middle meatus. In May, 1897, I passed a Lichtwitz trocar through the lower nasal meatus into the antrum and injected warm boric acid lotion. A little offensive pus came away; there was no return of the smell until June 4th. On June 10th, under cocaine, I opened up the antrum through the alveolar process. Up to the present there has been no retarn of the smell.

These three cases seem to prove that empyema of the maxillary antrum often exists without any of the alarming symptoms which are described in text-books. As a matter of fact, cases of disease of the antrum are fairly common, but are in most cases overlooked. I have purposely not entered into the details of the operation or the etiology of: empyema of the maxillary antrum. The less severe cas $\mathrm{e}_{\mathrm{g}}$. are most frequently due to disease of the mucous membrane. of the nares. I have also avoided entering into the detain of differential diagnosis between the diseases of the maxillary antrum and those of the sphenoidal or ethmoidal cells. Tha symptoms are in many cases very similar. Bradford.

\section{Clinital entes:}

MEDICAL, SURGICAL, OBSTETRICAL, AND THERAPEUTICAL.

\section{AN UNUSUAL INCIDENT IN LITHOTRITY.}

BY SINCLAIR WHITE, M.D. R.U.I., F.R.C.S. ENG:

A MAN, aged fifty-two years, was admitted to the Sheffield Royal Hospital on June 21st last for the removal of a vesical calculus of many years' standing. Two days lateir I proceeded to crush it, but after working for a few minutes the lithotrite jammed with the blades three-fourths of a inch apart. A surgical instrument maker was sent for, but he was unable to liberate the blades, which were, of course. much too far apart to allow of the instrument being witbdrawn. The only way of escape from the dilemma appeared to be in performing supra-pubic lithotomy. This was accordingly done, and after removing the stone we succeeded in protruding the blades of the lithotrite through the wound. They were then placed in a vice and pressed together untis the female blade fractured. The male blade could now be driven home and the instrument was removed. Had the vice failed us we were prepared to file through the projecting end of the male blade. Owing to the lithotrite being in the urethra the bladder could not be distended; but by using a large rectal bag no difficulty was experienced in reaching the bladder.

The stone, with the crushed débris, weighed one and a halk ounces, and was a typical oxalate of lime calculus. The lithotrite was an old one which had seen much service. Ths: patient is doing well.

Sheffield.

\section{NOTE ON A CASE OF RUPTURED DUODENEM: DEATH IN SIXTEEN HOURS.}

By NAPIER Close, L.R.C.P. EdiN., \&c., IATE HER MAJESTY'S CONVICT SERTICE.

ON June 24th last I was called in the evening to see a boy. thirteen years of age, who had been kicked by a horse early in the morning of the same day. I first saw him twelpe hours after the infliction of the injury, when his condition was as follows. He was lying in bed upon his back with tho hip-joints slightly flexed. His face was pale and wore an anxious expression. He complained of some pain in the lower part of the abdomen, which was slightly distended and very tender. There was no visible bruise or external wound. The abdominal muscles were rigidly contracted, which fact, combined with the tenderness, prevented the acquirement 0 any information from palpation. The percussion note was quite dull over the whole of the lower part of the abdomen and in the left flank. There was a band of tympanitic resonance below the costal margin and ensiform cartilage, and in the right flank also the note was tympanitic in character. The temperature in the mouth was $102 \cdot 5^{\circ} \mathrm{F}$. The pulse was 140 to the minute, rather small, but not thready. He was quite conscious, and gave me a connected account of the accident. The boy's father, who saw him immediately after the accident, told me that he was soon able to walk some distance up the field in which it had occurred, and then he lay down for some time. Subsequently he was taken home, and after the application of hot flannels he so far recovered that he was able to get about for some hours, and walked upstairs and downstairs. Towards evening be romited, and was sent for. Dr. Crosby, of Leicester, who was staying with me, kindly saw the patient, and we passed a catheter, drawing off clear urine without blood. From the symptoms 
nd examination we concluded that the boy had in all orobability sustained a rupture of the intestine, and that in inmediate laparotomy lay his sole chance of life. Accordingly asked Dr. Balfour, of Chard, to administer chloroform. Before Dr. Balfour's arrival the boy rapidly got worse; the pulse at the wrist became imperceptible, and the temperature fell to $97^{\circ}$. The lad was evidently dying, and under the - circumstances it seemed useless to risk the accusation of having killed him. He died absut an hour afterwards. Dr. Crosby told me that before death the abdomen became much more distended, with tympanitic percussion note all over, and loss of liver dulness.

By the coroner's order I made a post-mortem examination pourteen hours after death. The peritoneum contained about two pints of cloudy fluid, mixed with partially digested food. There were flakes of recent lymph adherent to the intestines, which were much reddened. On turning back the omentum and coils of small intestine a rent in the second part of the duodenum was revealed, from which the chyme was escaping. It was large enough to admit four fingers, and was distant four and a half inches from the pyloric orifice.

The case seems to me to be of interest from the fact that, motwithstanding the presence of such an extensive lesion in the abdomen, the boy was able to get about for several hours, and apparently suffered little pain. It was, in fact, difficult at first to persuade his parents that he was in imminent danger of death.

Dhard.

\section{NOTE ON A CASE OF PUERPERAL ECLAMPSIA.}

BY JOSEPH JOHN STACK, L.R.C.P. EDIN., L.R.C.S. IREL.

A MARRIED woman expected to be confined of her first child in the first week of September, 1896. During the early part of her pregnancy, which was wholly spent on board ship, she enjoyed the best of health, and was evidently looking forward with pleasurable anxiety to her approaching aternity. On reaching England, however, she seemed very such upset by hearing that her husband would shortly be out of employment. On the night of the bad news she was considerably alarmed at the fact that her ankles were much swollen, and that her boots seemed to be too small for her feet. This happened about the end of June. On July 3rd she consulted me about the condition of her legs, and at my request she cent me a sample of her uriue, which was passed scantily, and which upon examination was found to contain albumin to about one-twelfth of the specimen in the test-tube. For a few days after her visit $I$ attended her and strongly adrised her not to undertake the long journey to Ireland which she then contemplated for her accouchement. After some days' rest in bed the swelling in the legs more or less disappeared, but the albumin was still present in the arine. She was now affected with an irritable cough; the arms and hands began to swell, as also did her face. She complained of a severe pain over the left half of her head. On the night of July 16 th she had a severe attack of diarrhoea and vomiting, and on the following morning she was unable to remain in one position. She was now seized with convulsions, which continued off and on during the day, with only the intervention of the profound coma that succeeded each attack. All available classical medicaments were tried-chloroform was inhaled and chloral in twenty-grain doses was administered per rectum every two hours; but as the fits got more prolonged and the intervals between them began to decrease I, with the approval of a medical friend (Mr. H. J. Dixon), proceeded to bring on abour. This procedure was attended with considerable difficulty and anxiety. A uterine sound was first introduced so as to separate the membranes, and after some waiting 4 was able to introduce $m y$ finger-tip so as to feel the presenting head of the child, when I succeeded in puncturing the membranes with a hairpin straightened out. For some time after this there was an abatement in the symptoms; the fits did not cease, but they were not so frequent. The pains of labour now came on, and with each pain a fresh seizure took place. The patient was kept under chlor oform as much as seemed consistent with her safety, but the only course that seemed clear to me was to empty the uteras with all possible speed. I dilated she os uteri with my fingers, and after unsuccessfully attempting to introduce the forceps I turned and delivered

ber of a living male infant. She bad a slight convulsion after delivery. For some days afterwards the patient was in a rather low condition; the pulse was about 120 and the temperature ranged between $100^{\circ}$ and $103^{\circ} \mathrm{F}$. She was frequently syringed out with lysol, and iodoform was copiously dusted on the vulva. A little trouble with her breasts, which lasted for a week or so, cansed her to lose her spirits; but she eventually made a good recovery, and only regretted the loss of her infant. The urine was quite free from albumin two days after delivery.

I know that dilatation of the os and turning are both strongly deprecated by many of the leading lights of the profession; but under the circumstances I felt that I was obliged to have recourse to both measures. Stimulants, nutriments, quinine, and occasional douching were continued until convalescence.

New Cross-road, S.E.

\section{d :}

or

\section{HOSPITAL PRACTICE, BRITISH AND FOREIGN.}

Nulla sutem est alia pro certo noscendi via, nisi quamplurimas et morborum et dissectionum historias, tum aliorum tum proprias Morb., lib. iv. Proomium.

\section{ST. GEORGE'S HOSPITAL.}

A CASE OF ACUTE YELLOW ATROPHY OF THE LIVER IN A GIRL TWELVE YEARS OLD; NECROPSY.

(Under the care of Dr. CAVAFY.)

ACUTE yellow atrophy of the liver in many respects greatly resembles phosphorus poisoning; in fact, so great is the likeness that Munk, Wagner, ${ }^{1}$ and others have maintained that all cases of acute yellow atrophy are due to poisoning by phosphorus. It is said that the absence of leucin and tyrosin from the urine is against a diagnosis of acute yellow atrophy and in farour of phosphorus poisoning. The history of the following case is by no means unlike a case of sub-acute poisoning by phosphorus. Apparently no bacteriological examination was made; this would have been of great interest in view of the theory held by many that the disease is bacterial in origin. For the notes of the case we are indebted to Dr. E. T. Fison.

A girl, aged twelve years, was admitted into St. George's Hospital on March 10th, 1897. Three weeks previously she had complained of having general pains, which lasted three days; these were followed by what was thought to be a "bilious" attack, as shown by vomiting after food and headache. Since March 3rd she had been jaundiced. There was no history of fright or mental shock. When admitted the child was very jaundiced and looked ill. The temperature was $101.4^{\circ} \mathrm{F}$., and the pulse was 92 . The tongue was coated. There was much bile in the urine, but none in the fæces. Physical examination showed that the heart and lungs were normal, but the liver appeared to be enlarged and extended to three fingers' breadths below the costal margin. The child complained of persistent pain in the right hypochondrium, and was occasionally sick; her appetite was bad. The jaundice varied greatly in its intensity from day to day. The case seemed to be rather different from one of simple or catarrhal jaundice on account of the raised temperature and the enlargement of the liver; however, a provisional diagnosis of simple jaundice was made. By March 15th the temperature had reached normal, but the symptoms and jaundice remained the same. On the 20 th the liver appeared to be smaller, but the general condition was unaltered. On the 21st, at midday she suddenly became drowsy, she would not perform any action or answer questions, and she was unable to swallow. The reflexes were not abolished, but urine and fæces were passed into the bed. The temperature was slightly above the normal; there was no delirium. On the 22nd she remained in the same state, the liver appeared 